\title{
Comparative Studies on the Protein Profiles and Hydrophobicity of Strains of Streptococcus mutans Serotype $c$
}

\author{
By KENNETH W. KNOX, ${ }^{*}$ LYN N. HARDY ${ }^{1}$ AND \\ ANTHONY J. WICKEN ${ }^{2}$ \\ ${ }^{1}$ Institute of Dental Research, United Dental Hospital, Sydney, New South Wales 2010, Australia \\ ${ }^{2}$ School of Microbiology, University of New South Wales, Kensington, New South Wales 2033, \\ Australia
}

(Received 21 January 1986; revised 10 March 1986)

\begin{abstract}
Twelve strains of Streptococcus mutans serotype $c$ were grown in batch culture with glucose at constant $\mathrm{pH}(6.0)$ and a number of properties compared. On the basis of their cellular and extracellular protein profiles, the strains were divided into three groups, I, II and III, containing five, four and three strains, respectively. The extracellular protein profiles for a particular strain differed if the organisms were grown either at $\mathrm{pH} 6.0$ with fructose instead of glucose or with glucose but without $\mathrm{pH}$ control. The total amount of extracellular protein produced by group III strains grown in glucose-containing medium at $\mathrm{pH} 6.0$ was several times that produced by strains of groups I and II, which were also more hydrophobic. One of the potentially important proteins is P1, also called antigen B or I/II, and it was shown to be entirely in the culture fluid of group III strains but mostly cell-associated from strains of groups I and II. Approximately half of the cell-associated fraction of P1 could be removed with hot sodium dodecyl sulphate.
\end{abstract}

\section{INTRODUCTION}

The extent of genetic diversity in oral streptococci has led to those previously identified as Streptococcus mutans being reclassified into five species under the general name of mutans streptococci, with $S$. mutans strains now having a more restricted range of characteristics (Coykendall, 1977, 1983). Strains representative of the four species that are human commensals are also readily distinguishable on the basis of their extracellular protein profiles, with lesser differences between the protein profiles of strains from the different serotypes of $S$. mutans $(c, e$ and $f$ ) and Streptococcus sobrinus ( $d$ and $g$ ) (Hardy et al., 1986).

The aim of the present study was to determine the extent of variation in the cellular and extracellular protein profiles for 12 strains of $S$. mutans from the serotype that occurs most frequently, $c$. To increase the potential for genetic diversity, eight of the strains had been isolated from New Guinea indigenes whereas the remainder were from western communities, which had already received considerable attention. In previous studies (Hardy et al., 1981, 1986), where organisms were grown in continuous culture, protein production was shown to be influenced by the growth $\mathrm{pH}$ and by a change in carbohydrate from glucose to fructose. Accordingly, in the current study, where organisms were grown in batch culture, the pH was controlled (6.0) and the effects of glucose and fructose were compared. The protein profiles of representative strains grown without $\mathrm{pH}$ control were also examined to enable a comparison with the results of McBride et al. $(1984,1985)$. Particular attention was given to the protein

Abbreviations: LTA, lipoteichoic acid; RIE, rocket immunoelectrophoresis; SM, scanning microdensitometry. 
component designated $\mathrm{P} 1$, which is indistinguishable (Forester et al., 1983) from the previously described antigens I/II (Russell, M. W. et al., 1980) and B (Russell, R. R. B., 1979) and whose production was markedly affected by the growth conditions (Hardy et al., 1981; Forester et al., 1983).

The total amount of extracellular protein of molecular mass $\geqq 60 \mathrm{kDa}$ produced by the different strains was also estimated and compared with the hydrophobicity of the organisms as measured by adhesion to hexadecane (Rosenberg, 1984). There is evidence that surface proteins contribute to hydrophobicity (Weerkamp et al., 1982; Wadström et al. 1984), and the decrease in hydrophobicity of two strains of $S$. mutans serotype $c$ on repeated subculturing has been shown to be accompanied by the release of greater amounts of several proteins including antigens $B$ (McBride et al., 1984, 1985), A and C, and also lipoteichoic acid (LTA) (Russell, R. R. B. \& Smith, 1986).

\section{METHODS}

Organisms. Twelve strains of $S$. mutans serotype $c$ were chosen for study. Strains NGl-8 were isolated from dental plaque of New Guinea indigenes by Dr R. G. Schamschula (Institute of Dental Research, Sydney). The other strains were obtained from A. S. Bleiweis (University of Florida, Gainesville, USA), KPSK2 was from J. Carlson (University of Umeå, Umeå, Sweden) and two cultures of strain Ingbritt were from B. Krasse (University of Göteborg, Fack, Sweden), identified in our records as Ingbritt 162 (obtained in 1971) and Ingbritt 175 (obtained in 1973). All previous studies on strain Ingbritt (Jacques et al., 1979; Hardy et al., 1981; Forester et al., 1983) have used the strain now designated 162 . While all of these strains had been classified as $S$. mutans before the more restrictive definition was introduced, the presence of the type $c$ antigen is consistent with their continued classification as $S$. mutans (Coykendall, 1983; Schleifer et al., 1984).

All cultures were stored in the freeze-dried state, stocks being subcultured every 2-4 years.

Growth conditions. The growth medium consisted of the low $M_{\mathrm{r}}$ fraction of Trypticase (BBL Microbiology Systems)/yeast extract medium that passed through an Amicon hollow fibre filter H1P1O. Glucose or fructose was added to a final concentration of $2 \%(w / v)$ and the medium was then sterilized by membrane filtration (Hardy $e t$ al., 1981).

Cultures were grown at $37{ }^{\circ} \mathrm{C}$ in a Multigen fermenter (New Brunswick Scientific Co.) and gassed with $95 \% \mathrm{~N}_{2} /$ $5 \% \mathrm{CO}_{2}$. Unless otherwise specified, organisms were grown at a constant $\mathrm{pH}$ of 6.0 with the aid of an automatic $\mathrm{pH}$ controller (New Brunswick Scientific Co.). The rate of addition of $2 \mathrm{M}-\mathrm{NaOH}$ was monitored, and organisms were harvested as soon as possible after reaching stationary phase. In many instances fructose-grown cultures required longer than glucose-grown cultures to reach stationary phase though the yields were usually comparable.

Analysis of protein components of culture fluid. Culture fluids were concentrated 100 -fold and samples $(40 \mu \mathrm{l})$ analysed by SDS-PAGE (Knox et al., 1985; Hardy et al., 1986). Molecular mass standards obtained from Pharmacia were ferritin ( $220 \mathrm{kDa}$ ), phosphorylase $b(94 \mathrm{kDa})$, bovine serum albumin $(67 \mathrm{kDa})$ and ovalbumin $(43 \mathrm{kDa})$. Separated proteins were fixed and stained with $0.1 \%$ Coomassie brilliant blue R-250. All samples were examined on at least two occasions to confirm the reproducibility of the results. For the quantitative analysis of stained gels, bands were scanned at $590 \mathrm{~nm}$ with a Gelman ACT scanning microdensitometer, and peak areas were measured by an attached digital integrator. The maximum variation between duplicate experiments generally did not exceed $10 \%$.

Comparisons of the total amount of extracellular protein of molecular mass $\geqq 60 \mathrm{kDA}$ were made by scanning microdensitometry (SM) of gels and expressing the total area under the peaks as arbitrary SM units per $100 \mu \mathrm{g}$ cell dry wt.

Lysis of cells and cell wall preparations. Cell walls were prepared by mechanical disruption of organisms followed by treatment with boiling SDS (Knox et al., 1979, 1983). Cells and cell walls were lysed with M-1 $N$ acetylmuramidase kindly provided by Professor K. Yokogawa (Knox et al., 1983), and was continued until $\mathrm{OD}_{600}$ readings indicated that lysis exceeded $90 \%$.

Serological estimation of protein P1. The amount of protein P1 in culture fluid and in lysed whole cells and cell walls was estimated by rocket immunoelectrophoresis (RIE), using rabbit antiserum against protein P1 purified from the culture fluid of strain Ingbritt 162 (Forester et al., 1983).

Hydrophobicity. Cell suspensions $(1.2 \mathrm{ml})$ in $0.01 \mathrm{M}-\mathrm{Tris} / \mathrm{HCl}$ buffer, $\mathrm{pH} 7.0\left(\mathrm{OD}_{600} \cong 1\right)$, were vortexed for $2 \mathrm{~min}$ with $0.2 \mathrm{ml}$ hexadecane and the percentage reduction in the $\mathrm{OD}_{600}$ of the aqueous phase was determined (Rosenberg, 1984). The mean of six estimations was calculated. Although repeated subculturing ( $>30$ times) of $S$. mutans serotype $c$ strains can markedly decrease hydrophobicity (Westergren \& Olsson, 1983), it is unlikely that this would influence the current results where subculturing was kept to a minimum. 

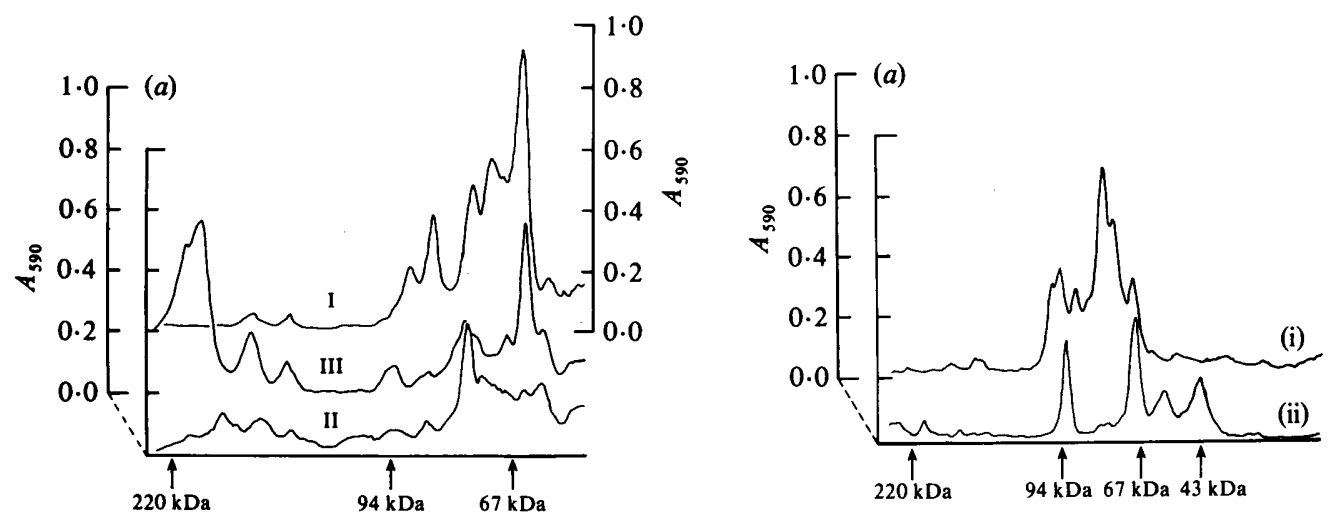

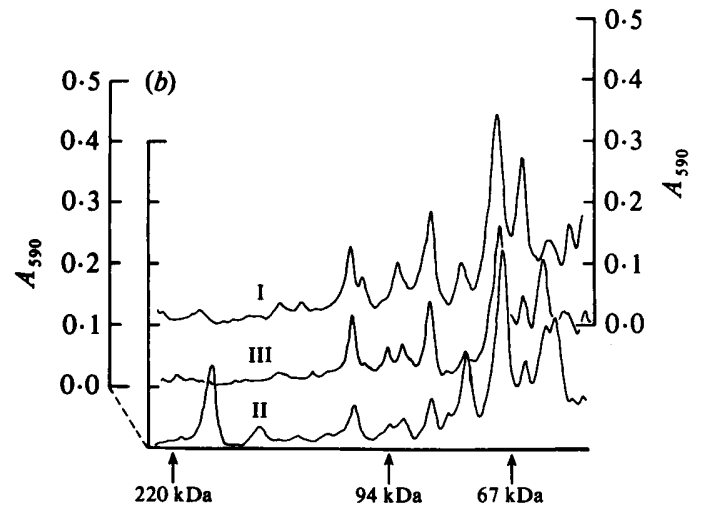

Fig. 1

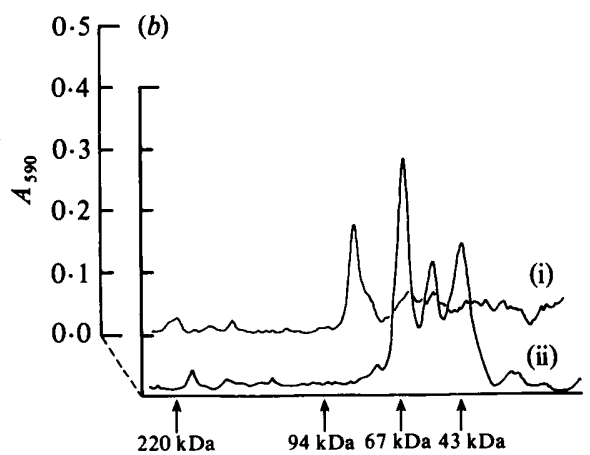

Fig. 2

Fig. 1. Microdensitometry scans after SDS-PAGE of $(a)$ extracellular and $(b)$ cellulaf proteins of strains representative of groups I (NG1), II (Ingbritt 175) and III (Ingbritt 162). The ordinates on the right relate to the group I strain and those on the left to the group II and III strains respectively. Migration distances for proteins of known molecular mass are also shown.

Fig. 2. Microdensitometry scans after SDS-PAGE of extracellular proteins produced by (a) strain NG1 and (b) strain NG3. Organisms were grown with glucose in batch culture at a constant pH of 6.0 (i) or without pH control (ii).

\section{RESULTS}

\section{Comparison of different strains grown at pH 6.0 with glucose}

Concentrated culture fluids of organisms were analysed by SDS-PAGE followed by SM to detect components within the molecular mass range 50-230 kDa. Restriction to this range enhanced resolution of the major components, and lower molecular mass components were present in relatively small amounts in such culture fluids (cf. Fig. 2). Similar analyses were done with organisms lysed with M-1 N-acetylmuramidase, where, on the basis of the known dry weight of organisms in the original culture, the volume of cell extract to be analysed was adjusted so that it was equivalent to the volume of culture fluid examined.

The extracellular protein profiles could be divided into three groups, which displayed greater diversity than the corresponding cellular protein profiles. Fig. 1 provides the results for $(a)$ extracellular and (b) cellular proteins of a typical strain from groups I (NG1), II (Ingbritt 175) and III (Ingbritt 162). A comparison of the extracellular protein profiles showed that group I strains were characterized by multiple bands in the 60-95 kDa region whereas group II strains had a single major band in this region. Group III strains typically had multiple bands in the 60-95 kDa region but differed from the other two groups by the predominance of proteins of 
Table 1. Comparison of the hydrophobicity of organisms grown in glucose-containing medium at pH 6.0 and the amounts of extracellular protein of molecular mass $\geqq 60 \mathrm{kDa}$

Organisms that had been divided into three groups on the basis of their protein profiles were tested for their hydrophobicity as measured by percentage decrease in optical density on shaking with hexadecane, and the total amount of extracellular protein of molecular mass $\geqq 60 \mathrm{kDa}$ expressed in scanning microdensitometry (SM) units per $100 \mu \mathrm{g}$ cell dry wt equivalent. The results are those for a typical culture of each organism. The maximum variation for determination of total protein was $10 \%$. The hydrophobicity value is the mean of six estimations that differed by less than $5 \%$; for different cultures the maximum variation, which was obtained with the intermediate values, was $20 \%$.

\begin{tabular}{clcc} 
Group & \multicolumn{1}{c}{ Strain } & $\begin{array}{c}\text { Protein } \\
\text { (SM units) }\end{array}$ & $\begin{array}{c}\text { Percentage } \\
\text { hydrophobicity }\end{array}$ \\
I & KPSK2 & $<2$ & 86 \\
& NG1 & 36 & 70 \\
& NG2 & 115 & 79 \\
& NG6 & 47 & 32 \\
& NG8 & 152 & 87 \\
II & Ingbritt 175 & 93 & 58 \\
& NG3 & 15 & 77 \\
& NG4 & 15 & 90 \\
& NG7 & 91 & 90 \\
III & Ingbritt 162 & 400 & $<5$ \\
& GS5 & 410 & $<5$ \\
& NG5 & 340 & 7
\end{tabular}

molecular mass $>95 \mathrm{kDa}$, particularly $130-155 \mathrm{kDa}$ and $185 \mathrm{kDa}$. The $185 \mathrm{kDa}$ component was also present as a major component in the cell extract of the group II strain (Ingbritt 175) (Fig. $1 b$ ). To aid the subsequent comparison of protein components, those in the molecular mass ranges $185-200 \mathrm{kDa}, 130-155 \mathrm{kDa}$ and $60-95 \mathrm{kDa}$ are designated $\mathrm{P} 1, \mathrm{P} 2$ and $\mathrm{P} 3$ respectively (cf. Hardy et al., 1986).

The strains assigned to each of the groups are listed in Table 1, which compares the total amount of protein of molecular mass $\geqq 60 \mathrm{kDa}$ (as measured by SM) with the values for hydrophobicity. Each of the group III strains produced considerably more extracellular protein and gave a very low value for hydrophobicity. Organisms with very high $(>85 \%)$ or very low $(\leqq 7 \%$ ) values gave consistent results when duplicate cultures were tested. However, the range for cultures with intermediate values was $\pm 10 \%$.

\section{Estimation of protein PI}

Cultures grown at $\mathrm{pH} 6.0$ in glucose-containing medium were further examined by RIE for differences in the amounts of P1. Analyses were done with culture fluids and with lysates of the respective whole cells and isolated cell walls of two representative strains from each of the three groups. From the known dry weight of cells from the culture, a direct comparison was possible between the results for culture fluid and cell extracts. The results (Table 2) reinforced the previous observations (Fig. 1) on differences in the amounts of P1 in the cellular and extracellular fractions of organisms of groups I or II and group III, and also indicated that part of the cellular fraction is located in the cell wall.

\section{Effect of growth conditions on extracellular protein profiles}

Eight representative strains were grown to stationary phase in glucose-containing medium without $\mathrm{pH}$ control. The culture fluids were examined by SDS-PAGE followed by SM, and the results compared with those for the same organism grown at $\mathrm{pH} \mathrm{6.0.} \mathrm{The} \mathrm{scans} \mathrm{for} \mathrm{two} \mathrm{typical}$ strains, NG1 and NG3, are shown in Fig. 2, and indicate that the culture fluids of organisms grown without $\mathrm{pH}$ control contain proportionately greater amounts of protein of relatively low molecular mass ( $\leqq 67 \mathrm{kDa}$ ) than those grown at constant $\mathrm{pH}$.

A comparison of the culture fluids of organisms grown at pH 6.0 with glucose or fructose also showed major differences, particularly with respect to proteins in the P1 and P3 regions (Fig. 3). 


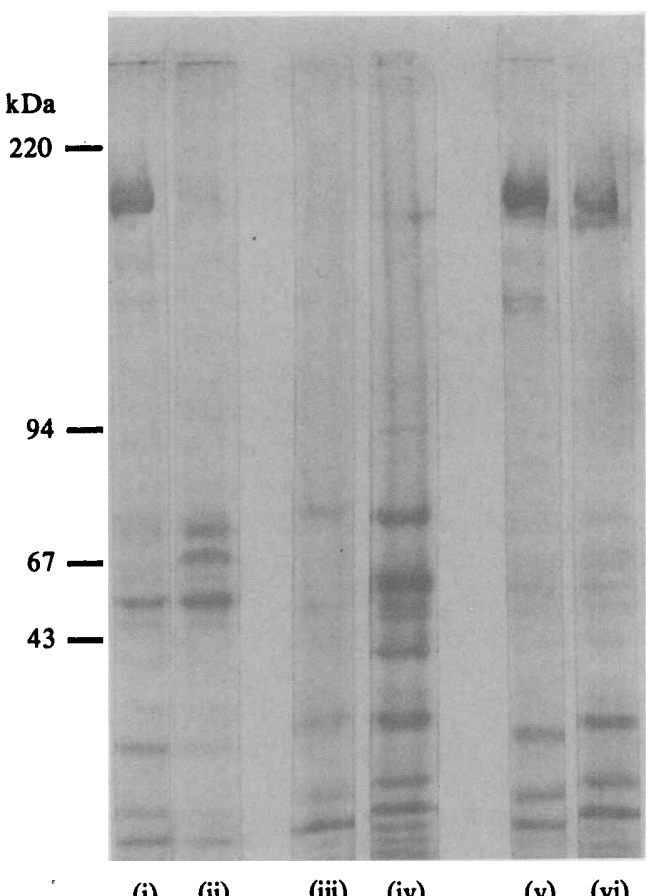

$\begin{array}{lllll}\text { (i) } & \text { (ii) } & \text { (iii) } & \text { (iv) } & \text { (v) }\end{array}$
Fig. 3. SDS-PAGE analysis of extracellular proteins produced by strains Ingbritt 162 , Ingbritt 175 and NG5 grown in batch culture at $\mathrm{pH} 6.0$ with either glucose (i, iii and $v$, respectively) or fructose (ii, iv and $v i$, respectively). The migration distances for proteins of known molecular mass are given.

Table 2. Quantification of protein PI by RIE

The $P 1$ content of culture fluids and of lysed cells and cell walls was estimated by RIE. Values were then calculated as rocket height in cm per $100 \mu \mathrm{g}$ whole cells or corresponding culture fluid, or per $100 \mu \mathrm{g}$ cell wall. The results are those for typical experiments, the maximum variation between replicates being $15 \%$.

\begin{tabular}{clccc}
\multirow{2}{*}{ Group } & Strain & Culture fluid & Whole cells & Cell wall \\
\cline { 3 - 5 } I & NG2 & 0.4 & 6.2 & 13 \\
& NG8 & 0.6 & 8.6 & 24 \\
II & NG7 & 0.2 & 7.4 & 23 \\
& Ingbritt 175 & $1 \cdot 5$ & 8.8 & 19 \\
III & Ingbritt 162 & 3.3 & ND & ND \\
& NG5 & $3 \cdot 1$ & ND & ND
\end{tabular}

ND, Not detectable.

For strain Ingbritt 175 the production of greater amounts of a number of extracellular proteins by fructose-grown organisms was associated with a decrease in hydrophobicity from $58 \%$ for glucose-grown organisms (Table 1) to $29 \%$. Strains NG1 and NG3 showed a similar trend with values of $70 \%$ and $77 \%$ respectively when grown in glucose (Table 1 ) and $34 \%$ and $48 \%$ respectively when grown in fructose. 


\section{DISCUSSION}

Examination of the characteristics of 12 strains of $S$. mutans serotype $c$ grown in batch culture has provided evidence of the extent to which closely related organisms can have major differences in their properties and the influence of growth conditions on these properties. Further, the range of differences was displayed by both the well-characterized type strains and a group of eight strains isolated from New Guinea indigenes.

The comparison of such results is dependent on the validity of the methods. Protein components were separated by SDS-PAGE, as this has proved to be more useful than isoelectric focusing (Hardy et al., 1981, 1986), and stained with a dye. Silver staining detects additional components (McBride et al., 1984, 1985) but dye-binding enabled comparison with previous results (Hardy et al., 1981, 1986), and focused attention on the major components. Further, it is presumed that the variations in the amounts of individual extracellular proteins are primarily. due to quantitative changes in the amounts secreted, although, as shown by previous studies on P1 (Forester et al., 1983), proteolysis may also occur and yield fragments of lower molecular mass. The results also stress the need to define the batch growth conditions, as the extracellular protein profile for an individual strain differed depending on the carbohydrate source and growth $\mathrm{pH}$. The effect of lack of $\mathrm{pH}$ control is particularly pronounced and is a factor requiring consideration when the results of different investigators are being compared.

A comparison of the results for strains grown in glucose at $\mathrm{pH} 6.0$ showed that they could be divided into three groups based on their extracellular protein profiles. Group III strains differed from strains of groups I and II with respect to individual extracellular protein components, particularly the greater amounts of protein of molecular mass $>95 \mathrm{kDa}$ including P1 (185 kDa). Strains of groups II and III were distinguishable by differences in the protein profiles of components in the $\mathrm{P} 3$ region $(60-95 \mathrm{kDa})$. Glucosyltransferase activity is associated with components in the P2 and P3 regions (Hardy et al., 1986), and proteins whose molecular mass falls within the $P 3$ range are a $74 \mathrm{kDa}$ glucan-binding protein (Russell, R. R. B. et al., 1983) and a $60 \mathrm{kDa}$ common antigen produced by a number of oral Gram-positive bacteria (Schöller $e t$ al:, 1982). Antigen B or I/II (P1) has received considerable attention because of tests on its use in a caries vaccine (Cohen et al., 1983), its biological properties (Cohen et al., 1983; Ayakawa et al., 1985), and its potential involvement in adhesion (Douglas \& Russell, 1984; McBride et al., 1985). The estimation of P1 by RIE confirmed and extended the results of SDS-PAGE. All the detectable P1 was in the culture fluid of the group III strains (Ingbritt 162 and NG5), whereas for the strains of groups I and II the extracellular fraction represented only $3 \%(\mathrm{NG} 7)$ to $15 \%$ (NG5) of the sum of the amounts present in the culture fluid and cell lysates. A portion of the cell-associated P1 of the strains of groups I and II was present in lysates of purified cell wall. Assuming that the wall accounts for approximately $20 \%$ of cell mass, it can be calculated that this fraction represented $43 \%$ (strains NG2 and Ingbritt 175) to $62 \%$ (strain NG7) of the total cellular P1. These quantitative analyses of $\mathrm{P} 1$ confirm and extend previous qualitative examinations of $S$. mutans serotype $c$ strains where the antigen (designated B or I/II) was shown to be present in lysates of purified cell walls (Russell, R. R. B., 1979) and was detected as a surface component by electron microscopy (Moro \& Russell, 1983). While it seems probable that those proteins that are so tightly associated with the cell wall that they cannot be extracted with hot SDS are bound covalently (Nesbitt et al., 1980), direct evidence is lacking.

The total amount of extracellular protein of molecular mass $\geqq 60 \mathrm{kDa}$ produced by group III strains grown in glucose at $\mathrm{pH} 6.0$ was considerably greater than that produced by strains of groups I and II, the respective means being 357 and $63 \mathrm{SM}$ units $\mathrm{ml}^{-1}$. Group III strains also gave much lower values for hydrophobicity as measured by adhesion to hexadecane. In confirmation of earlier studies on chemostat-grown organisms (Rogers et al., 1984; Knox et al., 1985), hydrophobicity values were also influenced by the growth conditions as shown by the differences for organisms grown in glucose or fructose. In the case of strain Ingbritt 175, the lower value for fructose-grown organisms was associated with greater amounts of individual extracellular proteins.

A correlation between decreased hydrophobicity and increased secretion of protein was also observed by McBride et al. $(1984,1985)$, who compared two hydrophobic and two hydrophilic 
strains grown without $\mathrm{pH}$ control. Antigen B was identified as one of the components (McBride et al., 1984, 1985), but the hydrophilic strains also secreted greater amounts of antigens A and C, as well as LTA, than the parent hydrophobic strains (Russell, R. R. B. \& Smith, 1986).

The secretion of greater amounts of proteins by hydrophilic strains is consistent with a role for surface proteins in hydrophobicity (Weerkamp et al., 1982; Wadström et al., 1984). LTA may also contribute to surface hydrophobicity (Miorner et al., 1983), and this is supported by recent studies on the critical micelle concentration of LTA (Wicken et al., 1986), which indicate that in aqueous solutions there is a significantly high concentration of the monomer with its exposed hydrophobic moiety.

While the significance of the absolute values for hydrophobicity is difficult to assess, strains of oral streptococci giving high values generally adhere more effectively to saliva-coated hydroxyapatite beads than those with low values (Gibbons \& Etherden, 1983; Westergren \& Olsson, 1983; McBride et al., 1985; Morris et al., 1985). A similar difference has been observed between Ingbritt strains 162 and 175, where the maximum value for bound cells approximated $3.4 \%$ of free cells for the hydrophilic strain 162 (cf. Campbell et al., 1983) and $8.5 \%$ for the more hydrophobic strain 175 (L. J. Markevics \& K. W. Knox, unpublished observations). For these reasons attention has tended to be directed towards the role of more hydrophobic organisms in dental plaque ecology (Gibbons \& Etherden, 1983; Rosenberg et al., 1983; Rosenberg, 1984). However, secretion by hydrophilic strains of much higher concentrations of a number of biologically active components could have particular significance.

We thank Rosemary Brown, Judy Evans and Henry Forester for their contributions to this study.

This work was supported by the National Health and Medical Research Council of Australia.

\section{REFERENCES}

Ayakawa, G. Y., Siegel, J. L., Crowley, P. J. \& BleIWEIS, A. S. (1985). Immunochemistry of the Streptococcus mutans BHT cell membrane: detection of determinants cross-reactive with human heart tissue. Infection and Immunity 48, 280-286.

Campbell, L. K., KnOX, K. W. \& WiCken, A. J. (1983). Influence of growth conditions on adherence of Streptococcus mutans Ingbritt to saliva-coated hydroxyapatite. Infection and Immunity 39, 445-448.

Cohen, B., Peach, S. L. \& Russell, R. R. B. (1983). Immunization against dental caries. In Medical Microbiology, Vol. 2. Immunization against Bacterial Diseases, pp. 255-293. Edited by C. S. F. Easmon \& J. Jeljaszewicz. London \& New York: Academic Press.

CoYkendall, A. L. (1977). Proposal to elevate the subspecies of Streptococcus mutans to species status, based on their molecular composition. International Journal of Systematic Bacteriology 27, 26-30.

CoYKendall, A. L. (1983). Streptococcus sobrinus nom. rev. and Streptococcus ferus nom. rev.: habitat of these and other mutans streptococci. International Journal of Systematic Bacteriology 33, 883-885.

Douglas, C. W. I. \& Russell, R. R. B. (1984). Effect of specific antisera upon Streptococcus mutans adherence to saliva-coated hydroxylapatite. FEMS Microbiology Letters 25, 211-214.

Forester, H., HuNTER, N. \& KNOX, K. W. (1983). Characteristics of a high molecular weight extracellular protein of Streptococcus mutans. Journal of General Microbiology 129, 2779-2788.

Gibbons, R. J. \& ETHERDEN, I. (1983). Comparative hydrophobicities of oral bacteria and their adherence to salivary pellicles. Infection and Immunity 41, 1190-1196.
Hardy, L. N., Jacques, N. A., Forester, H., Campbell, L. K., KnoX, K. W. \& Wicken, A. J. (1981). Effect of fructose and other carbohydrates on the surface properties, lipoteichoic acid production, and extracellular proteins of Streptococcus mutans Ingbritt grown in continuous culture. Infection and Immunity 31, 78-87.

HARDY, L. N., KNOX, K. W., Brown, R. A., Wicken, A. J. \& FitzGerald, R. J. (1986). Comparison of extracellular protein profiles of seven serotypes of mutans streptococci grown under controlled conditions. Journal of General Microbiology 132, 13891400.

JACQues, N. A., HARdy, L. N., Campbell, L. K., KNoX, K. W., Evans, J. D. \& WiCKen, A. J. (1979). Effect of carbohydrate source and growth conditions on the production of lipoteichoic acid by Streptococcus mutans Ingbritt. Infection and Immunity 26, 1079-1087.

Knox, K. W., Jacques, N. A., Campbell, L. K., WiCken, A. J., HuRst, S. F. \& Bleiweis, S. A. (1979). Phenotypic stability of the cell wall of Streptococcus mutans Ingbritt grown under various conditions. Infection and Immunity 26, 10711078.

Knox, K. W., Campbell, L. K. \& Bratthall, D. (1983). Detection of antigens in enzymic lysates of cell wall from Streptococcus mutans strains. Journal of Dental Research 62, 1033-1037.

KnOX, K. W., Hardy, L. N., Markevics, L. J., Evans, J. D. \& WiCKen, A. J. (1985). Comparative studies on the effect of growth conditions on adhesion, hydrophobicity and extracellular protein profile of Streptococcus sanguis G9B. Infection and Immunity 50, 545-554. 
McBride, B. C., Song, M., Krasse, B. \& Olsson, J. (1984). Biochemical and immunological differences between hydrophobic and hydrophilic strains of Streptococcus mutans. Infection and Immunity 44, 6875.

McBride, B. C., Morris, E. J. \& Ganeshuumar, N. (1985). Relationship of streptococcal cell surface proteins to hydrophobicity and adherence. In Molecular Basis of Oral Microbial Adhesion, pp. 85-93. Edited by S. E. Mergenhagen \& B. Rosan. Washington, DC: American Society for Microbiology.

Miorner, H., Johannsson, G. \& Kronvall, G. (1983). Lipoteichoic acid is the major cell wall component responsible for surface hydrophobicity of group A streptococci. Infection and Immunity 39, 336-343.

Moro, I. \& Russell, M. W. (1983). Ultrastructural localization of protein antigens I/II and III in Streptococcus mutans. Infection and Immunity 41, 410-413.

Morris, E. J., Ganeshixumar, N. \& McBride, B. C. (1985). Cell surface components of Streptococcus sanguis: relationship to aggregation, adherence and hydrophobicity. Journal of Bacteriology 164, 255262.

Nesbitt, W. E., Staat, R. H., Rosan, B., Taylor, K. G. \& DoYlE, R. J. (1980). Association of protein with the cell wall of Streptococcus mutans. Infection and Immunity 28, 118-126.

Rogers, A. H., Pilowsky, K. \& Zilm, P. S. (1984). The effect of growth rate on the hydrophobicity of the oral bacteria Streptococcus mutans and Streptococcus milleri. Archives of Oral Biology 29, 147-150.

ROSENBERG, M. (1984). Bacterial adherence to hydrocarbons: a useful technique for studying cell surface hydrophobicity. FEMS Microbiology Letters 22, 289-295.

Rosenberg, M., Judes, H. \& Weiss, E. (1983). Cell surface hydrophobicity of dental plaque microorganisms in situ. Infection and Immunity 42, 831-834.

Russell, M. W., Bergmeier, L., Zanders, E. D. \& LEHNER, T. (1980). Protein antigens of Streptococcus mutans: purification and properties of a double antigen and its protease resistant component. Infection and Immunity 28, 486-493.

RUSSELL, R. R. B. (1979). Wall-associated protein antigens of Streptococcus mutans. Journal of General Microbiology 114, 109-115.

Russell, R. R. B. \& SMith, K. (1986). Effect of subculturing on location of Streptococcus mutans antigens. FEMS Microbiology Letters (in press).

Russell, R. R. B., Donald, A. C. \& Douglas, C. W. I. (1983). Fructosyltransferase activity of a glucan binding protein from Streptococcus mutans. Journal of General Microbiology 129, 3243-3250.

SChleifer, K. H., Kilpper-Bälz, R., KRaus, J. \& GeHRING, F. (1984). Relatedness and classification of Streptococcus mutans and 'mutans-like' streptococci. Journal of Dental Research 63, 1047-1050.

SChÖller, M., Klein, J. P., SOMmer, P. \& FranK, R. (1982). Common antigens of streptococcal and nonstreptococcal oral bacteria: isolation and biochemical characterization of the extracellular protein antigen. Journal of General Microbiology 128, 21132120.

W AdSTRÖM, T., SchmidT, K. H., KüHnEmund, O., Havlícek, J. \& KohleR, W. (1984). Comparative studies on surface hydrophobicity of streptococcal strains of groups A, B, C, D and G. Journal of General Microbiology 130, 657-664.

Weerkamp, A. H., van Der Mei, H. C., Engelen, D. P. E. \& DE WINDT, C. E. A. (1982). Adhesion receptors (adhesins) of oral streptococci. In Bacterial Adhesion and Preventive Dentistry, pp. 85-97. Edited by J. M. Ten Cate, S. A. Leach \& J. Arends. Oxford: IRL Press.

Westergren, G. \& Olsson, J. (1983). Hydrophobicity and adherence of oral streptococci after repeated subculture in vitro. Infection and Immunity 40, 423435.

Wicken, A. J., Evans, J. D. \& Knox, K. W. (1986). Critical micelle concentrations of lipoteichoic acids. Journal of Bacteriology 166, 72-77. 